\title{
The Effect Of Bangkrut Fear On Motivation Students To Entrepreneurship
}

\author{
Ichsan Ali ${ }^{1}$, Suarlin ${ }^{2}$ \\ \{allink.unm@gmail.com $\left.{ }^{1}\right\}$ \\ ${ }^{1,2}$ Makassar State University, Indonesia
}

\begin{abstract}
This study aims to analyze why students find it difficult to become entrepreneurs. In this study the data collection technique used a questionnaire distributed to students of the Faculty of Education and the Faculty of Social Sciences at Makassar State University, and also used interviewing techniques to students and lecturers of the Faculty of Education. The sample used this research nature $d$ re s 50 Ponden by using purposive sampling and cluster sampling. The results of the study showed that students nowadays did have the talent for entrepreneurship but he was anxious about his business not running or afraid of going bankrupt. Bankruptcy is to suffer large losses to fall (about companies, shops, etc.); or it can also be referred to as out of business.
\end{abstract}

Keywords - Entrepreneurship, students, fear of going bankrupt, Risk

\section{Introduction}

At present, the development of entrepreneurship is a topic that is favored in industrialized countries . Fostering entrepreneurship through education and training has also increased in several universities in Indonesia. In this context, educated entrepreneurs are very important . The role of universities in motivating students to become young entrepreneurs is very important in growing the number of entrepreneurs. The role of the university in developing interest in entrepreneurship and exploring several factors that influence entrepreneurial behavior have been explored by several researchers (Autio et al., 1997; Dujin, 2005 cited in Venesar, 2006). These studies explain that entrepreneurial interest that can be directed through entrepreneurship education is influenced by attitudes and interests towards entrepreneurship. Therefore, this research attempts to examine student interest in entrepreneurship in Makassar State University students who are studied according to personality and student characteristics through questionnaire data collection techniques and interviews .

In developed countries the role of entrepreneurship is very dominant in supporting the growth of the economy and development. However, in developing countries like Indonesia, there are very few people who want to become entrepreneurs, even though economic growth is very much influenced by their existence. One of the reasons for the lack of entrepreneurship in this country is the lack of interest in entrepreneurship among students. Some of the factors causing low interest in entrepreneurship in students are due to lack of knowledge and self-confidence in entrepreneurship, plus the mindset of most education science faculty students who think that entrepreneurship has a high risk because it can lead to bankruptcy and requires large capital to be successful in entrepreneurship.

\section{Problem}


From the background above, the problems that exist in students are that students tend to be less interested in becoming entrepreneurs. Further research needs to be done on how student interest in entrepreneurship. The research questions that will be studied are:

1. What factors cause students to be less interested in entrepreneurship?

2. What should be done to make students aware of the importance of entrepreneurship?

3. What should be done to increase students' interest in entrepreneurship?

\section{THEORY}

\section{Important Steps in Starting a Business}

Roger Cartwright (2003) in his book entitled Private Entrepreneurs write ten steps that will help an entrepreneur in starting his business. And here are the ten steps:

a) Look for products, services, ideas, and so on that are offered by others. Entrepreneurs bring everything forward, they never

hoping to enter into an area and be the same as others. They will want:

- Do something similar, but present in a different way

- Do something new, but present it in ways that are already mine

- Do something new, and present it in ways that are also new

b) Determine the Steps to Obtaining the Required Resources For Then Implementing It. Some things need to be done to facilitate this implementation, including:

- Looking for business partners

- Looking for funding

- Copyright registration

- Deploy agent or dealer

- Creating a manufacturing organization

- Compile logistics and marketing

c) Get to know the external environment

Entrepreneurs need to think about overall external factors before starting to develop a project, because careful consideration of these factors will give an indication of potential opportunities and threats.

d) Know Yourself and Your Environment

An entrepreneur needs to think of strengths and weaknesses that are present. Weaknesses can often be overcome by recruiting people who serve as complementary strengths.

e) Master the Skills and develop the strengths that you have . Determine the skills - the skills or the skills required

by using existing resources, such as:

- Books or journals

- A variety of courses and training

- Colleagues or friends

f) Consider All Risks Existing and Never Fear For Failure Risks need to be analyzed carefully. If failure due to risk taking is not too dangerous for your business, it might be a valuable risk that you need to take.

g) Determine Your Goals

Each vision requires steps to then see the possibility of realization. It is also important to realize that the targets set must be dynamic and change to follow the environmental environment that surrounds them. 


\section{h) Communicate Your Vision}

Whatever the vision of an entrepreneur, the vision and goals associated with it must be communicated to all those involved in achieving that goal. Vision must be a shared vision if you want everyone to be totally involved.

i) Get Support

An entrepreneur needs support from both professional and family members. Continuous support from providers, colleagues, suppliers, staff and consumers is obviously Sangatvital to achieve success in any business.

j) Build Your Network

An entrepreneur usually seldom wasted the opportunity to build his network. Their books and personal notes are full of business addresses and contacts. They really realize the role that business partners play in their success.

\section{Risk taking}

Willingness and ability to take risks is one of the main values in entrepreneurship. It is in this situation of risk and uncertainty that entrepreneurs make decisions that contain potential failures or successes. The choice of this risk is very dependent on: The appeal of each alternative 1). Ready to suffer losses 2). The relative possibility of failure or success 3 ) The ability to take risks is determined by: Confidence in yourself. 4) Willingness to use abilities in exploring opportunities 5). and the possibility of making a profit. Ability to realistically assess risk situations. 6). Entrepreneurship is full of risks and challenges, such as competition, prices go up and down, goods don't sell and so on. But all of these challenges must be dealt with in a calculated manner. Therefore, risk takers are found in innovative and creative people who are the most important part of entrepreneurial behavior. Geoffrey G. Meredith in Suryana, (2001) suggested the characteristics and character of entrepreneurship, namely taking the risk of being brave and being able to take work risks and like challenging jobs .

\section{METHOD}

The type of research used in this study is qualitative research descriptive. In this study researchers examined the factors that caused students to be less interested in entrepreneurship. The population in this study were active students of the Faculty of Education, Makassar State University. In this study the sampling technique used questionnaires and interviews.

\section{RESULTS}

Based on the distribution of questionnaires that have been distributed to respondents, we obtain results, namely as follows:

1. Based on the first question, regarding the capital of young entrepreneurs (students) there are several kinds of opinions that they give. Among them are those who say that it is a very good thing because it can become capital in the future to become a successful entrepreneur, can be used as motivation in life. There were also 11 people who argued that he would borrow from his parents because he reasoned he was still in school and was dependent on his parents, but he would return it if the capital had returned. Other opinions also say that it depends on the opportunities that are owned, and can support the business that will be developed. Some even want to use their own money by setting aside a little money.

2. The second question, regarding the plan that the respondent will live through if he wants to entrepreneurship is accompanied by the reasons. There are many types of entrepreneurship 
that he will run, including some who want to sell food such as heavy food, snacks or chips and even cakes, especially food that hits because now there are many different types of food forms and flavors that are different from the taste in initially, other reasons were also due to hobbies in cooking or making food ... There were also those who wanted to open a fashion business, salon and online business such as make up tools, clothes, bags, headscarves, shoes, which people are using even more so when it's a discount and it's also supported by the development of technology today. There are also those who want to open a service business such as printing college assignments or school assignments online and offline, online is opened because seeing now students who have a lot of assignments but most are lazy to go out to print or print themselves. And offline alone because of the frequent occurrence of students or ordinary people who are queuing because of the many who want to print their assignments. Other reasons are also those who want to open a mini market, because there are many people who prefer to shop in the mini market, especially if they are in a place that lacks sellers, while also being supported by friendly and polite service that attracts buyers. There are also those who want to make souvenirs because they really like to make works such as key chains, pictures, flower buckets, and other types. There is also another astonishing opinion, namely the boarding house business because of the increasing number of students or communities from rural areas who migrate to the city so that they need a place to live.

3. The third question, regarding the interest of students in entrepreneurship at a young age, is that there are 28 respondents who answered Yes, and there were 2 respondents who answered no.

4. The fourth question, regarding the reasons students are not interested in entrepreneurship at a young age. Results obtained by 5 respondents answered that he was lazy, 5 respondents who answered he had no intention of entrepreneurship, and 20 respondents said they did not know where to start .

5. The fifth question, regarding the views of respondents to students or young people who are lazy in entrepreneurship around them. What factors cause them to be less interested in entrepreneurship. The results obtained stated that there were 18 respondents who answered they were afraid of going bankrupt, there were also 7 respondents who stated that due to reasons of prestige or environmental factors, the remaining 5 respondents stated that because the students were lazy in opening a business.

6. The sixth question, regarding actions that must be taken to make students aware of the importance of entrepreneurship. The results obtained were as many as 7 respondents who chose the step, namely socializing about the importance of entrepreneurship, as well as 22 respondents answered giving motivation about the atmosphere of life in the future, and 1 respondent who preferred the step of asking for advice to parents.

7. The seventh question, regarding actions that must be taken to increase students' interest in entrepreneurship. The results obtained indicate that as many as 16 respondents who said given concrete examples eg young entrepreneurs are successful, there are also two respondents chose was flawed by his parents, also there are 11 respondents who said that he must cultivate goodwill in themselves, and one respondent mengat a right by trying it first.

8. Eighth question, concerning respondents were told to choose between wanting to become a young entrepreneur or staying focused on college but parents always supported to stay in college. The results were 3 respondents who had the heart to become entrepreneurs, there were 11 who chose to follow the words of their parents, and the rest answered themselves that is to want to study entrepreneurship as much as 16 respondents. 
9. The ninth question, is an example of a situation where a student chooses which one to prioritize. For example, a student has a certain amount of money that can be used to open a business, but there are many college needs that he wants to buy. So from the results we got, there were 3 respondents who chose to continue their business but sacrificed their college needs, and also as many as 19 respondents who chose to continue their lecture needs but sacrificed effort. Apart from that, there are also those who have their own opinions, namely there are as many as 3 respondents who chose both, 3 respondents chose the most important first, and 2 respondents chose college requirements but also set aside some of their money.

10. The tenth question is the last question, about respondents being told to choose the path when they graduate . the results obtained were as many as 12 respondents chose to continue their education, there were also 4 respondents chose to open a business, 1 respondent chose to marry, 12 respondents chose to register cpns, and another answer was continuing their education when they were successful in running their business.

\section{DISCUSSION}

Based on the results of interviews conducted by 20 respondents from Makassar State University faculty of education and lecturers about why students are less interested in entrepreneurship? then the results are that students are basically mostly having an interest or for entrepreneurship but also inseparable from inhibiting factors such as assignments that take a lot of time, are lazy, do not know where to start, initial capital and lack of motivation or knowledge about entrepreneurship. But it also does not rule out the possibility of a small number of students who do not have the intention to entrepreneurship because they want to focus more on college.

Based on the results of filling out the questionnaires that we distributed to educational science students and the social sciences faculty as many as 30 respondents, the results of most education science students have an interest in entrepreneurship but there are some obstacles that become obstacles so students will think twice to open a business or to entrepreneurship. Like the fear of self, for example, being afraid of going bankrupt and not knowing where to start a business.

The following are outlined things that hinder students in entrepreneurship based on findings, the first fear of bankruptcy as many as 25 respondents stated that one that makes students not interested in entrepreneurship is because of the fear that arises in individuals to start a business, this is due to some respondents wanted to open a business that needed a lot of capital. With the presence of fear of bankruptcy or not the return of capital, students are discouraged or not interested in entrepreneurship.

The second is the prestige or environmental factor of 10 respondents stating that one that makes students not interested in entrepreneurship is due to environmental factors or the sense of prestige that exists in the individual to start a business. The third factor is Lazy as many as 9 respondents stated that one that makes students not interested in entrepreneurship is because there is a sense of laziness in him. Like they spend more time with their cellphones or are more happy with the world of gadgets, they prefer to go for dimoles, sleep at home or boarding houses, and be busy with their activities or hobbies. That is what causes students to be lazy or not interested in entrepreneurship.

Educational science students provide a variety of answers on what should be done to make students aware of the importance of entrepreneurship, but the first choice or most choice of students is to give students motivation about the atmosphere of their future lives. And also 
things that are done to increase students' interest in entrepreneurship are that most elementary school teacher education students in the education science faculty prefer to grow intentions first in themselves and besides that so that the intention can develop and can last a long time, it is necessary to provide concrete examples like young successful entrepreneurs at a young age who have many assets and can help their future.

In this study using questionnaire data collection techniques and interviews, it was found that the most influences students so students are not interested or difficult to entrepreneurship because of the fear of bankruptcy. This fear of bankruptcy caused student motivation in entrepreneurship to shrink.

\section{CONCLUSION}

Bankruptcy is suffering heavy losses . Based on the data that has been collected, mostly students of Faculty of Education, University of Makassar has the intention to entrepreneurship but because of their fear of going bankrupt within yourself so that affects the motivation of students in entrepreneurship.

\section{BIBLIOGRAPHY}

Adnyana, IGLA \& Purnami, NM (2016). Effect of Entrepreneurship Education, Self-Efficacy and Locus of Control on Entrepreneurial Intention. E-Journal of Management of Unud, 5 (2), 2016

Bruce, R. A. 2009. Exploring the psychological hardiness of enterpreneur. $\quad$ Presented at the Babson Enterpreneurship: University of Lousville.

Bungin, B. 2007. Metodologi Penelitian Sosial. Surabaya: Airlangga University Press.

Creswell, J. W. 2010. Pendekatan Kualitatif, Kuantitatif, dan Mixed. Yogyakarta: Pustaka Pelajar.

Herdiman, FS 2008. " Young Entrepreneurs Start from the Family Environment". http: // journals nasional.com/media, downloaded on March 12, 2011. 